\title{
Correction to: Characterizing the cultural evolutionary process from eco-cultural niche models: niche construction during the Neolithic of the Struma River Valley (c. 6200-4900 BC)
}

\section{Brent R. Whitford ${ }^{1}$}

Published online: 10 May 2019

(C) Springer-Verlag GmbH Germany, part of Springer Nature 2019

\section{Correction to: Archeological and Anthropological Sciences} https://doi.org/10.1007/s12520-018-0667-x

The lists of archeological settlements represented by Figs. $3 \& 4$ in the original publication were unfortunately mislabelled by the author. Amended figures with the correct labelling have since been submitted. The author would like to apologize for any inconveniences caused and wishes to assure his readers that the error in question has not otherwise adversely affected the presentation of the data, analysis, results, or any of the interpretations made herein. Given in the article are the correct figures.

The online version of the original article can be found at https://oi.org/ $10.1007 / \mathrm{s} 12520-018-0667-\mathrm{x}$

Brent R. Whitford

brentwhitford@trentu.ca

1 Anthropology Graduate Program, Trent University, 1600West Bank Drive, Peterborough, ON K9L 0G2, Canada 


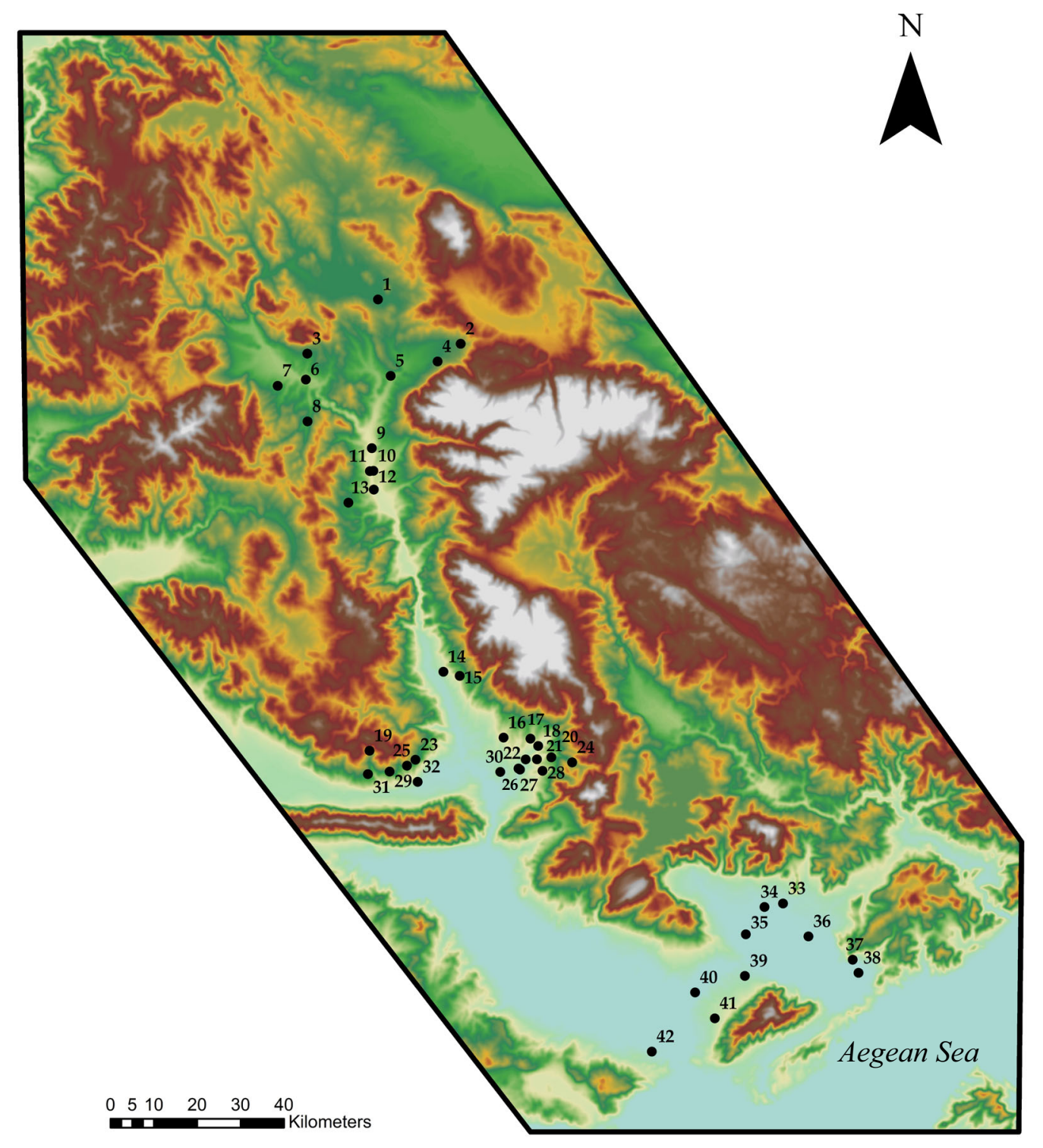

1. Galabnik

2. Saparevo

3. Tavalichevo-Gigan

4. Sapareva Banya-Krevnik

5. Dupnitsa

6. Nevestino-Moshteni

7. Bersin

8. Vaxevo-Studena Voda

9. Mursalevo

10. Kocherinovo-Quartal Levski
11. Kocherinovo-Lilacheto

12. Balgarchevo

13. Drenkovo-Gurleshki Nivi

14. Ilindentsi

15. Ploski

16. Vinogradi

17. Chereshnitsa II

18. Kovachevo

19. Baskaltsi

20. Petrovo I
21. Kalimantsi

22. Katuntsi III

23. Churichene

24. Goleshovo

25. Dolna Ribnitsa

26. Katuntsi I

27. Katuntsi II

28. Yanovo

29. Vishlene

30. Harsovo
31. Gega

32. Parvomai

33. Arkadikos

34. Chorla

35. Sitagroi

36. Doxaton

37. Dikili Tash

38. Polystylon

39. Nea Baphra

40. Dimitra

41. Mikro Souli

42. Kryoneri

Fig. 3 Middle Neolithic settlements 


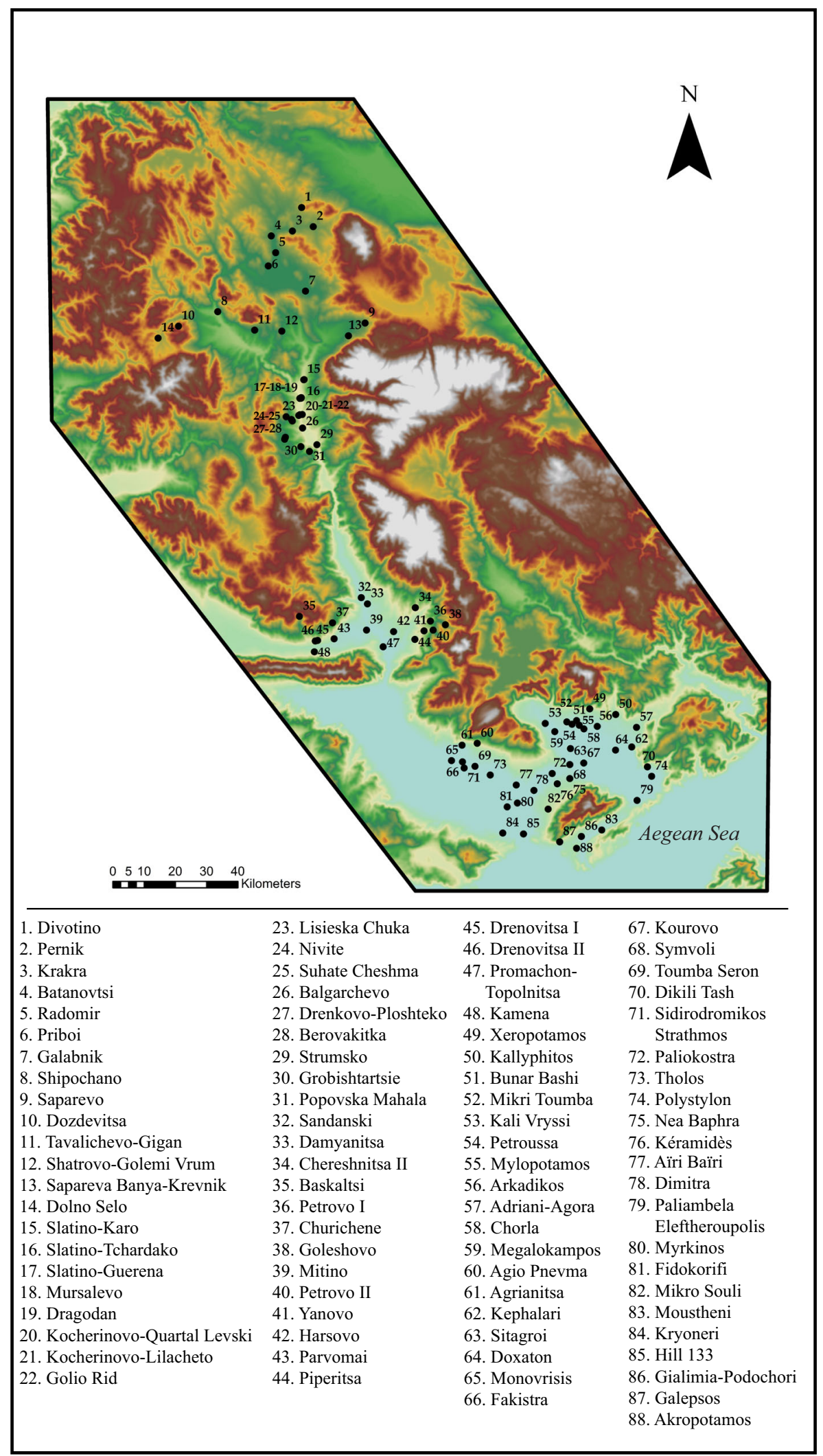

Fig. 4 Late Neolithic settlements

Publisher's note Springer Nature remains neutral with regard to jurisdictional claims in published maps and institutional affiliations. 